\title{
Papering over the Cracks? \\ Paperhouse as a 'Make-over' of Catherine Storr's Marianne Dreams
}

\author{
David Rudd
}

$\mathrm{L}$ ike tomboy girls in children's fiction, frequently described as being, at best, 'as good as' boys, but never good in their own right, so too filmic adaptations of classic texts are frequently seen in terms of their approximation to some ur-text, never being given independent recognition as artistic products. Such attitudes have been justifiably criticised and there now exists an extensive vocabulary for classifying adaptations, such as Geoffrey Wagner's tripartite division: moving from the faithful 'transposition', through 'commentary', where the core is retained, though 'either purposely or inadvertently altered in some respect' because of 'a different intention on the part of the film-maker' (1975, p.224), to 'analogy', 'which represents 'a fairly considerable departure for the sake of making another work of art' (p.226)

In this article I want to look at Catherine Storr's 1958 children's book, Marianne Dreams, and the $1989 \mathrm{film}$, Paperhouse, which seems to hover uneasily between 'commentary' and 'analogy'. My approach is predominantly Freudian, despite the fact that psychoanalytic approaches are frequently derided in children's literature for being far-fetched, it being argued that no child would ever see such (sexual) meanings in a work. However, this does not alter the key point that children's literature is written by adults who are, almost without exception, on the far side of puberty. Storr's work, it seems to me, is particularly open to a psychoanalytically informed approach, for two main reasons. First, Storr was herself a child psychiatrist, and has both written and spoken extensively about the importance of fearful material in children's writing (e.g. Storr, 1970; 1976). The second reason for adopting a Freudian approach is more oblique, arising out of the strange neglect the book has suffered, given that it is frequently acknowledged as a classic of the 'second golden age' of English children's literature. Thus Kimberley Reynolds, one of the very few critics to discuss it, notes its curious absence from the Rustins' Narratives of Love and Loss, though in many ways it would seem central to their Kleinian stance (1994, p.41). To me, it seems that Storr's novel has been ignored precisely because it does not so easily fit such popular notions of 'golden-ness', Unlike Pearce's contemporaneous Tom 's Midnight Garden, for instance, Marianne Dreams has no secret garden in which the child protagonists can recuperate; indeed, in many ways the desolate landscape of the latter seems to deliberately revoke such comforting images. Marianne's dreamworld is a much less determinate or sanguine realm. The film adaptation, in turn, has exploited this darkness, reworking the book as a horror story, incorporating some startling visual imagery (the director. Bernard Rose, went on to adapt Clive Barker's horrifying tale, 'The Forbidden', as Candyman in 1992). This said, I shall broadly argue that though more horrific in its presentation, the film is in fact far more conservative in its message than the book.

First though, a brief resumé of Storr's book. It centres on Marianne, whose sudden illness on her tenth birthday leaves her bedridden. She passes her time drawing, then finds herself entering her drawings during her dreams. Her drawings begin with a house, where she subsequently meets a boy, Mark, also ill, whom she helps recover, simultaneously aiding her own development. In the dreamworld the two are forced to undertake a dangerous journey from their once safe house, which becomes threatened by malevolent boulders, to a lighthouse, and thence beyond this, to the sea. In the end. Mark, now better, returns to the primary world (we presume), whereas Marianne is left alone in the secondary world.

The film has altered this plot in a number of ways, but there are three key changes: the fermale protagonist (Anna. in the film) is older; Anna's malevolent father moves to the centre of the tale, largely replacing the malevolent boulders; lastly, Marc (as he is in the film), dies at the end. There are a number of other alterations, more a result of the change of medium, which I shall address in passing, but I shall concentrate on these three main issues.

\section{ADOLESCENCE}

Anna is clearly an older child, approaching menarche. It is not simply that she is a year older (it opens on her eleventh birthday); she is visually represented as far more mature. In the book, Marjorie-Ann Watts' drawings, excellent though they are in capturing the desolate house set in its malevolent landscape, emphasise just how young Marianne is, and seem to query any notion of her 
being on the verge of adolescence. The film more successfully shows her caught between girlhood and adolescence. Anna's bedroom still has its teddy-bear lampshade and other childhood trimmings, but it is regularly juxtaposed with a darker alternative world one inhabited by males. Whereas we see Anna enjoying childish games of hide and seek, we also see her experimenting with make-up, enquiring of her more sophisticated friend what 'snogging' boys is like. The film skilfully contrasts such innocent pastimes with their darker underside, whether drawing pictures, or, indeed, in hide and seek, which ends in Anna being found by the police (aided by wolf-like alsatians), after she has passed out in a disused railway tunnel. The film very successfully captures Anna's confused and liminal status, whereas, as I said earlier, Marianne simply appears too young for such adolescent quandaries. (The fact that Storr wrote another novel about Marianne and Mark, as adolescents, suggests that Storr herself was aware of more mature issues that might still be addressed.)

This filmic change not only strengthens the storyline, but also allows Rose to introduce a horror dimension, something often used in films associated with girls approaching menarche (most famously in Carrie-. See Sobchack 1986, for a discussion of terrorized children in horror films). Anna's confused and feverish mental state is thus given a powerful, visual impact. Lastly, the practical reasons for Rose's shifting emphasis should not be forgotten: a film needs to appeal to a wider, less segmented audience, hence another reason for the shift to a proto-adolescent, especially given the vogue for horror treatments of such topics.

\section{THE DREAMSCAPE}

The film's shift to a horror treatment is not outlandish, though, for Storr's book is itself disturbing, especially in the way she eerily captures the unworldly feel of a dreamscape - even down to the experience of trying unsuccessfully to run: 'her legs wouldn't move quickly enough, her feet seemed to stick to the ground' (p.29). There are primitive symbols aplenty: malevolent stones, the deformed house, a stunted tree, a lighthouse - let alone a boy and girl. This elemental feel is emphasised in the minimalist chapter titles, too: 'Inside', THEM', 'The
Light' and so on. Such stark symbols set up a Manichaean struggle between light and dark - ultimately, in fact, between life and death. Moreover, not only do the symbols work in their own right; they also skilfully refract what is happening in the primary, everyday world. At the beginning, for instance, when Marianne first visits her dreamscape, it is described thus:

She was in a great open stretch of country, flat like a prairie, covered, as far as she could see. with the long dry grass in which she was standing more than knee deep. There were no roads, no paths, no hills and no valleys. Only the prairie stretched before her on all sides till it met the grey encircling sky.

(pp.19-20)

This landscape sounds straight out of Van Gogh - his 'Wheatfield with Crows', in particular, which also offers its viewer no escape route; as the omniscient narrator puts it, 'There seemed to be nothing to do and nowhere to go' (p.20). This is exactly Marianne's predicament as an invalid. We are also given intimations of what might happen to her if she does not heed her doctor's advice, as we observe the wind make the dream landscape writhe, blowing 'the thin thread of smoke ... out like a candle flame' (pp.21-2).

The smoke, of course, is rising from the house that Marianne drew once she learned that she was housebound. Our actions, then, as in Freud's conception, are seen to be motivated by unconscious concerns. A house represents shelter, a place of retreat - which is exactly what Marianne, like some wounded animal, needs. It is an effective 'objective correlative' for her, finding herself confined to bed. Notably, it is when Marianne begins to feel better that she draws herself a path - an escape route. Marianne's drawings, then, are an expression of her psychological state. Likewise, her dreams, as in Freud, pursue these psychological concerns. However, as Freud also noted, dream images tend to condense a number of meanings in a very succinct and powerful way. Storr herself has endorsed this view of fantasy writing:

It is immensely rich and at the same time it 's very economical. When you move between the world 
of reality and the world of imaginationyou acquire overtones, you can suggest much more than you ever actually have to say.

(1970, p.29)

Her writing certainly manages to preserve a dreamlike suggestion of profound meanings, without settling on any one interpretation. Thus the symbolic potential of the house is not yet exhausted. Not only is it a protective, womb-like structure, but it is also emblematic of woman. Thus it is significant that, largely thanks to Marianne, the two children come to be threatened by 'Them' - seven 'humped squat figures' (p.l05) with their single 'great eyeballs [which] swivelled in their stone sockets' (p.108). These hunks of stone seem to show an emerging phallic awareness on the part of their dreamer, as they gather round the female house in which the two children hide. Reynolds, in calling the stones 'giant stone erections' (1994, p.41), clearly feels the same. Moreover, there would seem to be echoes of Freud's Wolf Man, too. The Wolf Man, it might be recalled, dreamt that he looked out of his home window and saw seven, large, white, motionless wolves, staring fixedly at him - figures that are also given a sexual significance by Freud.

But the stones not only convey a sense that eros is present. but thanatos too. With their cold, inert presence, they suggest non-existence as they watch, vulture-like, for any deterioration in the children's health-Mark's especially. 'They want to hurt us somehow', as Mark says (p.120), and, indeed, we do later witness them crushing the children's bicycles with a sound 'like the pounding of a giant pestle in a huge mortar' (p.172).

Marianne's budding sexuality therefore starts out as something frightening: a destructive force for which she is unprepared; it destabilises her old identity as a confident 9-year-old, one who, at the beginning of the story, envisages climbing on a horse and instantly riding like an expert. Only later can she come to terms with these feelings, when, accompanying Mark, she makes a far more unsteady journey to that more overtly phallic structure, the lighthouse (though again, this too signifies in more than one way, contributing to the overall Manichaean imagery of light and dark).
Other elements would seem to sustain a reading along these lines; for instance, there is the almost biblical, 'little stunted apple tree with some apples on it. They didn't look ripe, but yet they also didn't look exactly unripe' (p.42). Locked in a period of latency, the two children do not yet seem to be fully aware of the facts of life. But during the book we see each move away from this selfcentred isolation, epitomised in their respective illnesses. Storr sensitively handles this awkward, fumbling affection, as when Marianne helps Mark onto his bicycle. 'clutching Mark's flesh unmercifully through his pyjama jacket' (p.136).' Slowly each comes to terms with the opposite sex. In Jungian terms (which Storr seems to find more amenable), they are on the path to individuation, each discovering their respective animus /anima. Marianne's comment, speaking of her male counterpart, captures this: 'We're just the opposites, him and me, aren't we? ... It's a pity you can't mix us up a bit...' (p.32). The book ends with them being more united, but the film, though it also uses these lines, does not.

Paperhouse maintains many of the above elements, creating a very disturbing alternative real $\mathrm{m}$, but it changes the emphasis, chiefly by making the father central, and subsuming other elements to his pivotal presence. The title itself reflects this shift. moving from Marianne's development and the role that dreams play in it, to a more general concern with home. Like 'paper promises', 'paperhouse' suggests that her house is one in name only, and, sure enough, we find that Anna lives alone with her mother, her father working away on an oilrig. There is also the suggestion that her father's absence is not only physical; that there are tensions, too, in her parents' relationship, which are later given some substance when we hear that her father drinks. This notion of the dysfunctional family certainly gives the film a more contemporary feel.

The father is a shadowy, absent figure in the early part of the film. Anna would quite like him to return, but she also fears him - and males in general. We observe her faint three times: first after she appears disturbed by a male teacher in the school corridor; second, in a railway tunnel after she has been discussing boys; and third, and most powerfully, when she is in her mother's darkroom, where 
the latter, a photographer, is developing a print of Anna's father. As his outline develops, Anna's mother is saying 'They might frighten, but they can never hurt you'. Though she is speaking about dreams, the juxtaposition obviously makes us think of fathers. As his image comes into focus Anna faints - and the photo turns darker, more malevolent. We then see Anna recovering, relaxing in a hot bath, recalling taking the photo of her father, seated on a rock. Suddenly, he becomes animated - as pictures do for Anna - leaping up to grab her. The shot then cuts back to a naked and vulnerable Anna, choking as she emerges from her bath water. Males, then, disturb Anna; and, significantly, she is always in a confined space when this happens, precipitating her into the initially wideopen dreamscape.

What skeleton there is in the family cupboard to cause this fear is unclear. But without doubt the unknown father is the motivator. He effectively takes over the function of the phallic boulders. The stones hardly feature in the film until the father appears, whence we see him outlined alongside them, against a deliberately close and claustrophobic horizon (we also have his association with rocks in the picture Anna took). In a clever reversal, Rose has the father blinded (as a result of Anna's scribbling over his face in her picture, perhaps hinting at being 'blind drunk'), whereas, in the book, it is the normally blind stones that are given vision. Also, it is the father who smashes up Marc's bicycle.

But the father is not simply a blind madman. Anna is clearly ambivalent about him, which is why she wants to introduce him into her picture in the first place - to rescue Marc, despite the latter's reticence. In fact, we realise that she has been experiencing this ambivalence earlier, as has her mother too. Rose portrays this with a subtle reworking of the game of hide and seek. Firstly, Anna plays it with her friend, who counts the requisite 100, after Anna. notably, has made herself alluring with some gaudy make up. Then the game is re-enacted in a far more powerful and elemental play of hunter and hunted in the dreamscape, with the blinded father counting out the seconds before he pursues his daughter. During this, Marc is hurled aside when he.tries to intervene and it ends in a profoundly disturbing scene where Anna's father violently pummels her in the chest, suggesting rape. However, the game is also cleverly alluded to between these episodes, in the darkroom scene, where the mother is counting out the time needed for the father's image to develop. She too, seeks the hidden father.

What difference does the invading father make, then? I think it results in quite a profound shift in the power of the tale, and its message to the audience. For the book seems to present us with a far more female-centred realm. The male members of Marianne's family - her brother and father - are shadowy figures, never featuring in any of the scenes. Even the holiday at the end is organised by the mother (pp.181-2). Females and their crafts are foregrounded. Marianne, for instance, makes a patchwork for her governess; she also possesses a much-loved woollen blanket called 'Joseph' which, we learn, was collectively knitted (p.89); but most significantly, there is 'greatgrandmother's old polished mahogany workbox' (p.15), containing sewing materials and 'The Pencil'. In the film there is little of this notion of female solidarity and power; indeed, Anna vents much of her frustration on her mother, who seems to take the blame for the absent father (this said, Rose has sensibly made the doctor female, running this character together with the governess of the book, achieving a wise economy whilst simultaneously giving the work a more contemporary feel).

The book, then, refreshingly seems to view creativity as a more female, craft-like, demonstrative and communal venture. The pencil itself, amongst the sewing things, is linked with such female arts as spinning tales, weaving texts, and drawing out threads. It not only anticipates Gilbert and Gubar's subsequent, celebrated opening sentence of Madwoman in the Attic (1979) - 'Is the pen a metaphorical penis?' (p.3) - but suggests an original response, of sorts. That is, Storr's text does not seem to accept that the pen/cil is simply a weapon of creativity that men control, in the way that they author(ise) patriarchal culture in general, effectively trapping women:

As a creation 'penned' by man ... woman has been 'penned up' or 'penned in.' As a sort of 'sentence' man has spoken, she has herself been 'sentenced' ... As a thought he has 'framed', she has been both 'framed' (enclosed) in his texts. 
glyphs, graphics, and 'framed up' found guilty. found wanting) in his cosmologies

(Gilbert and Gubar, 1979, p.13)

In Marianne Dreams this position is reversed, in that it is Marianne who frames the male - appositely named as Marianne's pencil 'Mark'. Not only this, but the book also undercuts the traditionally male idea of an allpowerful, all-controlling singular creator, as the text endorses creativity's interconnected, relational nature. Hence the drawn (Mark) also has a hold on the draw-er (Marianne), effectively drawing her in. Furthermore, Marianne cannot draw any old thing, only that which is psychologically apposite. The pencil, in fact, is less concerned with denotation than connotation: it responds to underlying needs rather than surface features. It is also continually stressed that Marianne does not have complete control over the process, any more than she does over her dream-life. Both arise from her unconscious.

So Marianne finds that she is involved with real concerns, not just paper figurings. She might have sketched a boy's face simply 'because it was easiest to draw' (p. 25) but she soon finds that he is more than just a pencil 'mark' 'It's decent of you to allow that I may be a real person after all, and not just part of your scribblings' (p.65). As her animus, he becomes animated, and she finds herself increasingly involved with him, both psychologically and emotionally. And through him she comes to put her own situation in perspective. Certainly, she hates 'having to wait for the things she wanted which were out of reach and had to be brought to her' (p.48), but she sees that this is as nothing compared to Mark's predicament.

However, it is only gradually that she comes to use the pencil in a responsible way. The book shows us both the constructive and destructive potential of the imagination, linking it to thanatos. Thus we witness Marianne, in a fit of jealousy, scoring 'thick lines across and across and up and down over the window' (p.53) where Mark's face is. 'She scribbled viciously over the face in her picture, and felt as if really it was Mark she was destroying', simultaneously saying to herself, 'I wish he was dead'. The house ends up looking like a prison, which Marianne enhances with a higher fence and by giving each large boulder a single eye, making them look like guards.
Notably, this precedes reality, for we later learn that Mark has deteriorated, has been put in an iron lung, in fact, and will clearly be under close surveillance (as it is later put, 'He was in hospital ... being watched by nurses and doctors and his parents for signs of getting better: or worse' - p.110). It is only subsequently, however, that Marianne realises that, because they share the same psychological space, she will also suffer as a result of her actions. As Mark says to her while they are within their psychological prison, '.. this isn't a dream... This is real' (p.83) - and, of course, their suffering, their confinement, is completely real.

Marianne does learn, however, and although she initially pens Mark in, as men confine women in so many cultural stories, she later sees just how foolish and dangerous such action is:

The house, and the stunted garden, were hemmed in, toocramped and small: and the evil, watching stones made it seem even more of a prison. (p.115)

Thus she learns, instead, to help Mark grow, allowing him take control of his own life, at the same time aiding her own development.

Paperhouse keeps the creative aspect intact, especially near the beginning, where we see Anna, like an artist possessed, putting everything into her paper creation. However, the film plays down the links with female crafts; and though we always see Anna using the same pencil, it is not given any matriarchal significance; thus. in hospital, she simply requests her 'pencils and ... drawings'.

More importantly, the value of this alternative world is seriously questioned in the film.

Rather than a space in which problems can be worked through and development occur, the dreamworld of the film seems to be more intrusive and, in some respects, destructive. Aside from Marc's death, for example, there is the issue of Anna's relation to her father. It is certainly not in the dreamworld that she learns how to get on with him-in fact, quite the opposite. The dream version of her father turns out to be a complete travesty: dreams have led 
her astray. So what purpose do they serve? The main message seems to be that they are an untrustworthy source of information; rather than providing deep insights, they seem to be misleading, the product of an afflicted mind.

This is particularly demonstrated in the scene where Marc sets in train the removal of Anna's father (it is of note, too, that Marc takes control here) by directing Anna's dreamworld hand, so that, in the everyday world, her hand also moves, reaches out for her drawing and tears out the offending figure of her father. This one-toone correspondence between the two worlds, the easy access and correction of one by the other, clearly undermines the potential of the dreamworld in the book. It also makes the actions in the everyday world the decisive factor: reality is the saviour, not fantasy. The reason why the film does this, and what it offers instead, I shall return to shortly.

\section{THE ENDING}

As Shelley O'Hearn notes, in the only in-depth discussion of Marianne Dreams that I have seen, the ending is most unusual for a children's book. Rather than closing in the primary world, with things back to normal, Storr's book ends in the alternative realm. Not only that, but in many ways it seems a precarious state, for she has bequeathed Mark her special pencil, giving him, in effect, control of the dreamworld. Mark, however, has already left, although a picture and note explain his departure in a helicopter (in which, somewhat ominously, 'they' have collected him), saying that he will be back. It ends:

Mark would come: he would take her to the sea. Marianne lay down on the short sweet-smelling turf. She would wait, too.

(p.191).

She is content, though there seems an element of unease here, too. This said, Reynolds' comment that 'Mark ... has died and that in lying down to wait for him Marianne is choosing death too' $(1994$, p.43), is surely going too far - albeit the openness of the text does not rule it out completely (although the later text, Marianne and Mark, does retrospectively preclude it).
The unease, rather, comes from Marianne passing control over to Mark: not only have the two moved to the phallic lighthouse - arguably an indication of Marianne coming to terms with a patriarchal world - but the pencil, Gilbert and Gubar's metaphorical penis, has also been passed (back) to the male. Once again the female might seem penned in, albeit of her own free will, with Marianne saying to Mark, 'You draw me in the tower' (p.185). On the one hand this might seem a depressing ending (although it is something to which many girls can relate: they excel till puberty, then start to lose confidence and the boys start to shine - a process charted by Lyn Mikel Brown and Carol Gilligan, 1992). This is the thrust of O'Hearn's article, calling the book an example of the 'stifled female quest', noting similarities between Marianne's fate and that of Mary Lennox in The Secret Garden: 'Marianne becomes the passive, feminine caretaker of the unconscious world so that Mark can assume his position in the external one' (p.39); she exhibits 'a type of death... trapped in the feminine role she was compelled to create' (p.40). However, as critics have also claimed with The Secret Garden, this is not what many carry from the book.

As has already been observed, Storr's novel resists the standard closure (which the differing interpretations mentioned by Reynolds and O' Hearn attest). so, although there is certainly a notion of the patriarchal order reasserting itself at the end, it is not determinate. It has that ambiguity and uncertainty that Todorov (1975) saw as central to the fantastic. Like The Secret Garden, the book seems more generally to prioritise the female realm. Marianne is no longer selfish, recognising that Mark can never achieve independence while she provides for him; hence Marianne gives him the means to be self-reliant, magnanimously bequeathing him her pencil. It has already done its work for her, allowing her to come to terms with herself; in fact, with her consent it seems to have 'deliberately drawn itself' into the dream world, 'and ... said good-bye' (p. 183)

This, I would say, is also in line with a female notion of creativity: a relational, communal activity. Significantly, Mark, in a more self-centred and isolated way (he insists on drawing in private) achieves nothing but his own escape. His picture, too, is noteworthy, and perhaps 
explains his inability to achieve more, being 'a neat workman-like drawing', the tower drawn 'with mathematical precision' (it is certainly a less overtly phallic structure than earlier), with a 'very efficientlooking helicopter' overhead (pp.190-1). As O'Hearn notes, Mark has also included some writing. In short, it is a much more defined, denotative creation, far less a product of the unconscious.

In itself this is interesting, but there is more. O'Hearn notes that the focus of the text's close is on Marianne, but her argument does not seem to take account of Marianne's mood: unlike the bleak, unbalanced Van Gogh landscape of the opening, all is in harmony here: "sunshine ... drowsy bees ... small lacy waves ...the sea and the land ... at peace ... even the dark country behind the hills was wrapped in a soft grey haze which was gentle, not frightening, at one with the beauty of the day' (p.191). In one way this is because Marianne has come to terms with a new side of herself, her male animus. Unlike earlier, it is no longer troublesome, needing to be contained; it can now come and go at will. From the other side, Mark has indeed drawn her into the picture (so she is part of his consciousness, too) but, pertinently, he has not drawn her 'in the tower'. Mark has not confined her as she did him: she has freedom in this realm; in fact, her tranquil mood suggests that she is at home in both realms now. Lastly, I think Marianne is content because not only is she convinced that Mark will return (the final picture, after all, does show her being rescued by helicopter), but also because she believes that, as a result of his departure from this realm, the two will now meet in real life, together in health just as their illness and loneliness first united them in the dreamscape (an anticipation realised in the sequel, Marianne and Mark). Indeed, Marianne openly speculates on them 'going to the same place' (p.188) when she knows that Mark is also going for a seaside holiday.

The film is far less ambiguous about events, not only in having the boy, Marc, die at the end, but, as I've argued above, in making patriarchy more central. This not only seems to undermine Anna's capability of effecting things through her dreams (as does Marianne), but undercuts the whole world of fantasy, seeing it as an unreliable distortion of reality. Thus, we learn that Anna is misguided: it was not abuse that she was experiencing at the hands of her father; rather it was essential heart massage from an ambulance-man. She also learns that Marc has not recovered; and, characteristically, it is her father who informs her that he's dead - 'characteristically' because the film all too easily falls into an oedipal pattern. On the one hand, Anna wants to summon her father to help Marc ('If my dad was here, he could carry you ... then you'd be safe'); on the other hand, he is a jealous father who wants to destroy his young rival. The father, blinded (castrated) by his daughter, casts aside the interloper, Marc, turning them both out of their paperhouse, and is then observed molesting his daughter - in the Freudian drama, something that she has desired all along.

However, the key point is that this is all a fantasy: misguided. In reality, the absent father is reinstated in her affections and, at the end, we see the family unit restored, father, mother and daughter: 'We can all be together like a proper family', as the father says, the message seeming to be that a father is necessary in order for this to happen. Anna's whole crisis of adolescence therefore remains unaddressed; or rather, is seen as easily brought under control by her returning father, as she in turn, is reinstated as his 'good girl'.

\section{CONCLUSION}

I have argued that Storr's work, bold and uncomfortable for its time, still has the power to shock and disturb. and, especially, still generates debate about its unsettling ending. The much more recent film, though visually disturbing, seems to avoid creating any underlying ideological tremors. It leaves things profoundly as they are. Indeed the horror element seems to act as a waming against disturbing the status quo. If fathers are absent. then this might be the consequence. So, happy families triumph, and budding adolescent sexuality is nipped rather than nurtured. Marianne's empowerment has been turned into Anna's retrenchment. Beyond this, the implication of the film is that a dream life is a dangerous and untrustworthy thing, rather than being therapeutic and informative. Fantasy thus becomes a snare rather than a way of discerning unconscious truths.

For an explanation of this curious shift - especially the 
imposition of the father figure - I think we need to look at the time when the film was made, which was one where a crisis over fatherhood was prevalent. In British society in particular there was growing concern over absent fathers, resulting eventually in the controversial 'Child Support Agency' of 1992; there was also increasing disquiet about male violence in the family. In fact, the traditional role of the male was generally seen as being in jeopardy, challenged both in their employment and their general deportment. Rose's film, however unconsciously, seems to respond to these concerns, seeking to exonerate the father, showing that his 'bad press' is often misplaced. In the process, Paperhouse ends up lending support to our culture's conventional, and more comfortable, reading of Freud; that is, one where the seduction theory was rightly rejected (the misplaced notion that children were really being abused by their fathers), in favour of this being a fantasy relation (one where the female child secretly desired to be seduced by the father). ${ }^{2}$ Made at a different time, I doubt whether the film would have made such an 'analogy' (in Wagner's terms), incorporating such an intrusive father figure - though it is still doubtful whether any film would have risked such an indeterminate and daring ending as the book.

\section{NOTES}

1 Shelley O'Hearn is mistaken, though, when she claims that Storr acknowledeges the children's 'bike ride away ... as a sexual metaphor' (1998, p.41), for the passage of Storr's that O'Hearn quotes is referring to a later book. where Marianne is on a boy's motorbike (Storr 1970, p.37).

2 For further discussion see Masson (1992). John Collick, in the only article on Paper House [sic] that I have seen, argues along similar lines, that the film followed the moral panic over child abuse and, in particular, the Cleveland Case, where the doctors who had accused families of abuse were themselves pilloried for accusing families in this way.

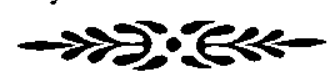

\section{REFERENCES}

Barker, Clive (1985) 'The Forbidden' in Clive Barker's
Books of Blood, vol. 5. London, Sphere.

Brown, Lyn Mikel and Gilligan, Carol (1992) Meeting at the Crossroads: Women's Psychology and Girls' Development. London, Harvard University Press.

Collick, John (1991) 'Wolves through the window: writing dreams / dreaming films / filming dreams Critical Survey 3, 3: 283-9.

De Palma, Brian (1976) Carrie. United Artists.

Freud, Sigmund (1995) 'From the history of an infantile neurosis ('Wolf Man')' in Peter Gay (ed.) The Freud Reader. London and Sydney, Random House, pp.40026.

Gilbert, Sandra and Gubar, Sandra (1979) The Madwoman in the Attic: the Woman Writer and the Nineteenth Century Literary Imagination. New Haven and London, Yale University Press.

Masson, Jeffrey (1992) The Assault on Truth: Freud and Child Sex Abuse. London, Fontana.

O'Hearn, Shelley (1998) 'Marianne Dreams, The Secret Garden and the stifled female quest', Papers: Explorations into Children's Literature 8, 1: 36-44.

Pearce, Philippa (1958) Tom 's Midnight Garden. Oxford, Oxford University Press.

Rose, Bemard (dir.)(1989) Paperhouse. Vestron Pictures/ Working Title Films.

Rose, Bernard (dir.) (1992) Candyman. Polygram Filmed Entertainment/Propaganda Films/ TriStar Pictures.

Reynolds, Kimberley (1994) Children's Literature in the 1880 s and the 1990s. Plymouth, Northcote House and British Council.

Rustin, Margaret and Rustin, Michael (1987) Narratives of Love and Loss: Studies in Modern Children 's Fiction. London, Verso.

Sobchack, Vivian (1986) "Child/Alien/Father: Patriarchal Crisis and Generic Exchange", camera obscura 15: 7-36.

Storr, Catherine (1958) Marianne Dreams. London, Faber \& Faber. 
Storr, Catherine (1960) Marianne \& Mark. London, Faber \& Faber.

Storr, Catherine (1970) 'Fear and evil in children's books', Children's Literature in Education 1, 1: 22-40.

Storr, Catherine (1976) 'Things that go bump in the night' in Nicholas Tucker (ed), Suitable for Children? Controversies in Children's Literature. Sussex, Sussex University Press, pp.143-52.

Todorov, Tzvetan (1975) The Fantastic: a Structural Approach to a Literary Genre. New York, Cornell University Press.

Wagner, Geoffrey (1975) The Novel and the Cinema. Rutherford N.J., Farleigh Dickinson University Press.

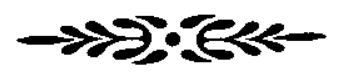

\section{BIOGRAPHICAL NOTE}

Dr David Rudd lectures in children's literature at Bolton Institute, UK. He has recently published articles on Bill Naughton, Rowling's 'Harry Potter', and Melvin Burgess's Junk. His latest book, Enid Blyton and the Mystery of Children's Literature is just about to be published by Macmillan.

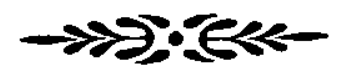

